\title{
Leggyakrabban használt kockázatkezelési modellek összehasonlítása
}

\section{Compare the most frequently used models of risk management}

\author{
T. JENEI \\ Debreceni Egyetem Műszaki Kar, Műszaki Menedzsment és Vállalkozási Tanszék, jeneit@eng.unideb.hu
}

\begin{abstract}
Absztrakt. A sikeres vállalati kockázatkezelés alapja, hogy a vállalat a múködéséből adódó kockázatokat jól felismeri-e, és hatékonyan tudja-e kezelni. Napjainkban a kockázatkezelésére többféle módszer áll rendelkezésre. Az egyes módszerek saját logikájuk szerint bontják lépésekre a kockázatkezelés folyamatát. Ebben acikkben négy kockázatkezelési modell összehasonlításával foglalkozom aszerint, hogy milyen azonosságok és eltérések vannak az egyes módszerek között.
\end{abstract}

Abstract. The successful risk management is based on the company can recognize and treat the risks well and effectively. Nowadays there are several techniques for risk management. Each technique breaks the risk management steps on its own logic. In this article we compare four different risk management models, accordingly what are the similarities, and what are the differences between the four models.

\section{Bevezetés}

A kockázatok kezelésében közös az, hogy mindig valamilyen véletlenszerű, számunkra veszélyt vagy kárt jelentő esemény bekövetkezése, vagy a bekövetkezéskor okozott kár mértéke elleni védekezésről beszélünk. Kockázatkezelésről akkor van szó, amikor az adott kockázati esemény felmerülése előtt tudatosan úgy alakítjuk a tevékenységünket, hogy azzal vagy a fenyegetést jelentő esemény bekövetkezési esélye, vagy az általa okozott kár kisebb legyen [5].Abban az esetben pedig,ha a káresemény már megtörtént, akkor tudatosan és felkészülten kezdjenek hozzá a kárelhárítási és újraépítési feladatokhoz.

Egységes, átfogó kockázatkezelési rendszer alkalmazásával biztosítható a vállalati stratégia meghatározása; a vállalati vagyon védelme; az átlátható működés biztosítása; a hatékony gazdálkodás támogatása.

A geotermikus beruházás esetén áttekintettük a kockázatelemzés, kockázatkezelés és kockázatkezelési stratégiák főbb értelmezését és alkalmazási lehetőségeit [7]. 
Az ISO 31000:2009 és ISO 31010:2009 alapján röviden áttekintettük egy vállat gazdasági folyamatai lehetséges kockázatait, a kockázatkezelés elemzését [8].

Jelen tanulmányban az ISO 31000:2009 mellett további három megközelítési módot (ERM, MoR, GCR) tekintünk át és hasonlítunk össze.

\section{Kockázatok kezelésének általános megközelítése}

A kockázatkezelés a kockázatok felismerésével, rendszerezésével, elemzésével foglalkozik. A kockázatkezelés egy gyűjtőfogalom, azoknak az eszközöknek és módszereknek az összessége, amelyek elősegítik a kockázatok azonosítását, számszerűsítését, hatásának mérséklését. A vállalat sikeres kockázatkezelési tevékenységének az alapja, hogy a vállalat működéséből adódó kockázatokat jól felismerie, és tudja-e a felismert kockázatokat hatékonyan kezelni. Felértékelődnek azok a módszerek, amelyekkel a különböző veszélyek, fenyegetettségek és ezek kockázatai tudatosan kezelhetők, illetve az ellenük való hatékony védekezés megvalósítható [9].

Azonban a kockázatkezelés nem szűnteti meg a kockázati tényezőket, csak abban segít, hogy a kockázat következményének hatása,maga a kockázat gazdaságilag számszerüsíthető és alakítható legyen. A kockázatkezelés nem egyszeri tevékenységet jelent, hanem ez egy ciklusosan ismétlődő folyamat, amit a szervezet vezetői és a munkavállalói hajtanak végre.

Egy vállalat számára kockázatot jelentenek azok a potenciálisan bekövetkező külső és belső események, zavarok, amelyek következtében veszélybe kerül a szervezet tevékenysége vagy bármely külső (vevő, szállítók, befektetők) belső (tulajdonos, munkavállaló) biztonsága. Leegyszerűsítve a kockázat alatt bizonytalan események negatív hatásait értjük.

A vállalati kockázatkezelés célja egy olyan rendszer kialakítása, amely a vállalati működés kockázataival és a bizonytalanságokkal foglalkozik, eközben támogatja és erősíti a vállalat stratégiai céljainak elérését. A szervezet kockázatkezelést a szervezet stratégiai céljainak meghatározása során az egész szervezet működésére, és a szervezetben zajló folyamatokra alkalmazza. Két szempontból lehet értelmezni a stratégiai kockázatkezelést:

- az egyik szempont szerint a stratégiai kockázatok kezelését jelenti,

- a másik szempont szerint a stratégiai kockázatkezelés egy olyan szervezeti keretrendszer kialakítását jelenti, melyen belül a szervezetben felmerülő mindenféle kockázatkezelését végzik.

Az egyes vállalatoknál a belső döntések és a külső környezeti hatások általában hordoznak valamilyen szintű kockázatot, hiszen nem tudható előre, hogy az adott esemény bekövetkezik-e, illetve milyen lesz annak hatása a vállalat mủködésére. A különböző típusú és hatású kockázatok ellen védekezni összetett és sokrétű feladat. Nem lehetséges minden egyes bizonytalan eseményre vagy veszélyre vállalati szintű kockázatkezelési eljárást alkalmazni. Azonban a vállalat működésének és eredményességének biztonsága érdekében, a vállalat szempontjából jelentős kockázatokat folyamatosan kezelni kell. 


\section{Kockázatkezelési modellek}

A kockázatok vállalati szintű egységes kezeléséről akkor beszélünk, amikor egy vállalat vagy valamilyen szervezet időben és egységes szempontok alapján kialakított keretrendszerben egyszerre többfajta kockázatot együttesen kezel [1]. Ennek megfelelően a vállalati kockázatmenedzsment alapvető feladata a vállalat biztonságos és hatékony múködésének fenntartása a különböző jellegű, előre nem látható események hatásaival szemben. Az integrált kockázatkezelés nem azonos azzal, hogy a vállalkozás különböző funkcionális területein elkülönülten folynak a kockázatkezelési tevékenységek, hanem azzal, hogy a belső szervezeti egységek összehangoltan, együtt végzik a kockázatkezelést, sőt a vállalkozás egészére készítenek kockázatkezelési stratégiát.

\begin{tabular}{|l|l|}
\hline Hagyományos kockázatkezelés & Vállalat szintű egységes kockázatkezelés \\
\hline A kockázatot egyedi veszélynek tekinti & $\begin{array}{l}\text { A kockázatot a vállalati stratégia részének } \\
\text { tekinti }\end{array}$ \\
\hline Kockázatazonosítás, kockázatértékelés & $\begin{array}{l}\text { Kockázati portfolió elkészítése, folyamatos } \\
\text { fejlesztése }\end{array}$ \\
\hline $\begin{array}{l}\text { Egyedileg, elkülönítetten foglalkozik a } \\
\text { kockázatokkal }\end{array}$ & $\begin{array}{l}\text { A hangsúly a kritikus fontosságú } \\
\text { kockázatokon van }\end{array}$ \\
\hline Kockázatcsökkentő válasz lépések & Kockázat optimalizáló válasz lépések \\
\hline Kockázati korlátokat, limiteket határoz meg & Kockázati stratégia kialakítása \\
\hline Nincs felelőse a kockázatoknak & $\begin{array}{l}\text { A kockázatoknak meghatározott felelősei } \\
\text { vannak }\end{array}$ \\
\hline Rendszertelen a kockázat számszerűsítése & Kockázatok folyamatos megfigyelése mérése \\
\hline „A kockázat nem az én felelősségem” & „A kockázat mindenki felelőssége” \\
\hline
\end{tabular}

1. táblázat: Hagyományos és a vállalati szintú kockázatmenedzsment összehasonlítása

(Forrás: [1])

A kockázatkezelésnek ez az új szemlélete a 2008-2010. között lezajlott pénzügyi válság után kezdett kialakulni. A vállalatok, szervezetek vezetői rájöttek arra, hogy a szervezetben felmerülő kockázatokat a továbbiakban nem lehet a korábban alkalmazott „hagyományos” módon kezelni. A válság előtti kockázatkezelési gyakorlatra az volt a jellemző, hogy a vállalkozás a működése során a felmerülő kockázatokat a vállalkozás vezetői felosztották a vállalaton belül a szervezeti egységek között, így az egyes kockázatokat több szakemberre bízva, külön-külön kezelték, a vállalat különböző területein.Az 1. sz. táblázat a hagyományos kockázatkezelés főbb működési szempontjait hasonlítja össze a vállalatirányítási folyamatok szintjére emelt, újszemléletű kockázatmenedzsmenttel.

A továbbiakban négy olyan kockázatkezelési keretrendszer mutatok be, melyek a vállalat irányítási rendszerébe integrálhatók. 


\subsection{ERM keretrendszer}

COSO ERM keretrendszer A COSO (Committee of Sponsoring Organizations of Treadway Commission) által a 90-es évek elején összeállított és folyamatosan fejlesztett vállalati kockázat kezelő (Enterprise Risk Management) keretrendszer a vállalat belső folyamataira, azok szabályozására és ellenőrzésére vonatkozik [3]. Az üzleti stratégiát szem előtt tartva minden kockázattípusra alkalmazható.

A COSO Bizottság 2012. január 20-án közzétette a kockázatviselési szint („risk appetite”, másképpen kockázatvállalási hajlandóság vagy kockázati étvágy) értelmezéséről és kommunikációjáról készült „Enterprise Risk Management - Understanding and Communicating Risk Appetite” című dokumentumát, melyben a 2004-ben kiadott ERM keretrendszer koncepcionális megközelítéseit és terminológiáját alkalmazva mutatja be a kockázatviselési szint és a kockázati tolerancia meghatározásának és alkalmazásának vállalatirányításban betöltött szerepét [3].

A COSO ERM definíciója szerint a kockázatviselési szint azt mutatja, hogy az üzleti stratégia vonatkozásában a vezetés és a felügyeleti testület (igazgatóság) mekkora kockázatot tart elfogadhatónak, míg a kockázati tolerancia azt, hogy a meghatározott kockázatviselési szinten a szervezeti céloktól milyen mértékű eltérés engedhető meg [3].

Az ERM egy folyamat, ami a szervezet egész területét érinti, a szervezet minden szintjén mindenki érintett, a szervezeti stratégia része, az egész szervezetben, annak minden szintjén/egységénél megjelenik. Célja, olyan lehetséges események azonosítása, amelyek ha felmerülnek, érinteni fogják a szervezet egészét, illetve a kockázati étvágy mértékéig a kockázatok kezelése. A kitűzött célok teljesítésével az ERM képes biztosítékot adni egy szervezet vagy vállalkozás vezetői számára [2].

Az ERM keretrendszer jól használható és érthető módon nyújt segítséget a vállalatirányításban közreműködő szakemberek számára, a vállalati kockázatkezelés végzése során kiemelt kérdésnek számító kockázatviselési szint meghatározásához és alkalmazásához. Vállalati, vagy az egyes szervezeti egységek szintjén, vagy működési folyamatok esetében meghatározott célokat és az azoktól való megengedett eltérést mutatószámokkal kell alátámasztani. Amíg a kockázati tolerancia esetében nem okozhat problémát a megfelelő mutatószámok alkalmazása, hiszen azok azonosak lehetnek a vállalkozás üzleti működésének eredményességét bemutató pénzügyi és egyéb teljesítménymutatókkal, addig a kockázatviselési szintek mérésére ezek közvetlenül nem alkalmazhatóak. A kockázatkezelés során a kockázatkezelési szint az, ami alapján a vizsgált kockázat besorolásra kerülés döntés születik arról, hogy milyen módon kezelik a felmerült kockázatot, azaz milyen kockázati válasz adható [12]. Ebből az következik, hogy ha nincs a vállalat, vagy a szervezeti egységek birtokában olyan objektíven mutatószám, ami a kockázatviselési szintre vonatkozik, akkora kockázatkezelés további lépéseit tárgyilagos döntésekre alapozva nem lehet végrehajtani.

A külső környezeti elvárások és a szervezet üzleti céljai szerint meghatározott és működtetett vállalatirányítási folyamatok a külső környezet által ismert legjobb gyakorlatokkal való hasonlítása azért valamilyen természetes mérték lehet. Minél teljesebb körben és mértékben tervezik megvalósítani az ismert legjobb gyakorlatokat, annál alacsonyabb az adott irányítási folyamat múködése során felmerü- 
lő, az üzleti célok elérését veszélyeztető kockázat. A kockázatviselési szint tehát meghatározható az egyes irányítási célkitűzések kapcsán alkalmazható legjobb gyakorlatok segítségével [2].

A szervezet reálisan megállapított, konkrét üzleti és múködési céljai azonban behatárolják azt is, hogy a szervezet optimális működtetése milyen költségeket visel el. Ennek megfelelően a kockázatviselési szintek megállapításakor a vezetésnek mérlegelnie kell a kockázatok esetleges negatív hatásának csökkentésével együtt járó költségeket is. Az alkalmazandó irányítási gyakorlatok tényleges, illetve várható költségeinek meghatározása szintén szükséges feltétele a különböző időhorizontokra és működési területekre vonatkozó üzleti céloknak megfelelő kockázatviselési szintek kijelölésének.

\subsection{ISO 31000:2009 szabvány}

Az ISO 31000:2009 [4] egy nemzetközi szabvány, amely irányelveket határoz meg a kockázatfelméréssel és kezeléssel kapcsolatosan. Ezt a szabványt bármilyen tulajdonformába tartozó (magán, állami stb.) vállalakozások, szervezetek alkalmazhatják, mert a szabvány nem szektor- és iparág-specifikus. Az ISO 31000:2009 szabvány a szervezetek működése során, a szervezeti tevékenységek, folyamatok széles körére alkalmazható, beleértve a stratégiaalkotást és döntéshozatali mechanizmust, működést, folyamatokat, funkciókat, projekteket, termékeket, szolgáltatásokat és eszközöket. A nemzetközi szabvány a negatív kimenetelű, bármilyen típusú kockázat mellett, a pozitív kimenetelű kockázatok esetében is alkalmazható. Az ISO 31000:2009 szabvány alapján a kockázatot, a bizonytalanság vállalati célokra való hatásaként értelmezik, így a kockázatkezelés folyamata a vállalati célrendszer egymásra épülő szintjein keresztül mutatható be. A kockázatfelmérésre és kezelésre vonatkozó tervek és keretrendszer megtervezése és végrehajtása során figyelembe kell venni a szervezetek speciális céljait, környezetét, struktúráját, folyamatait, projektjeit, termékeit, szolgáltatásait, eszközeit, és a szervezetek által alkalmazott speciális gyakorlatokat.

Az ISO 31000:2009 (Risk Management) szabvány által leírt kockázatkezelési alapelvek alkalmazása, a vállalati kockázatkezelés keretrendszerének ezen alapelvek szerinti kialakítása, valamint a szabvány alapján kialakított kockázatkezelési folyamatok vállalati működésbe való integrálása nagymértékben hozzájárulhat az eredményes és hatékony vállalatirányítás megvalósításához. Az ISO 31000:2009 Risk Management szabványa többi ISO szabványtól eltérően nem tanúsítható, de megfelelő keretet nyújt a vállalatok által alkalmazott és/vagy fejlesztendő kockázatkezelési gyakorlatok áttekintésére. A szabvány által meghatározott alapelvek (lásd. 1. sz. ábra) segítenek a kockázatkezelés vállalatirányítási keretekbe történő illesztésének megvalósításában.

Az ISO 31010:2009 [5] alapján a kockázatmenedzsment három fő részből áll:

- A kockázatmenedzsment alapelvei

- A kockázatmenedzsment keretmodellje

- Kockázatmenedzsment folyamata 


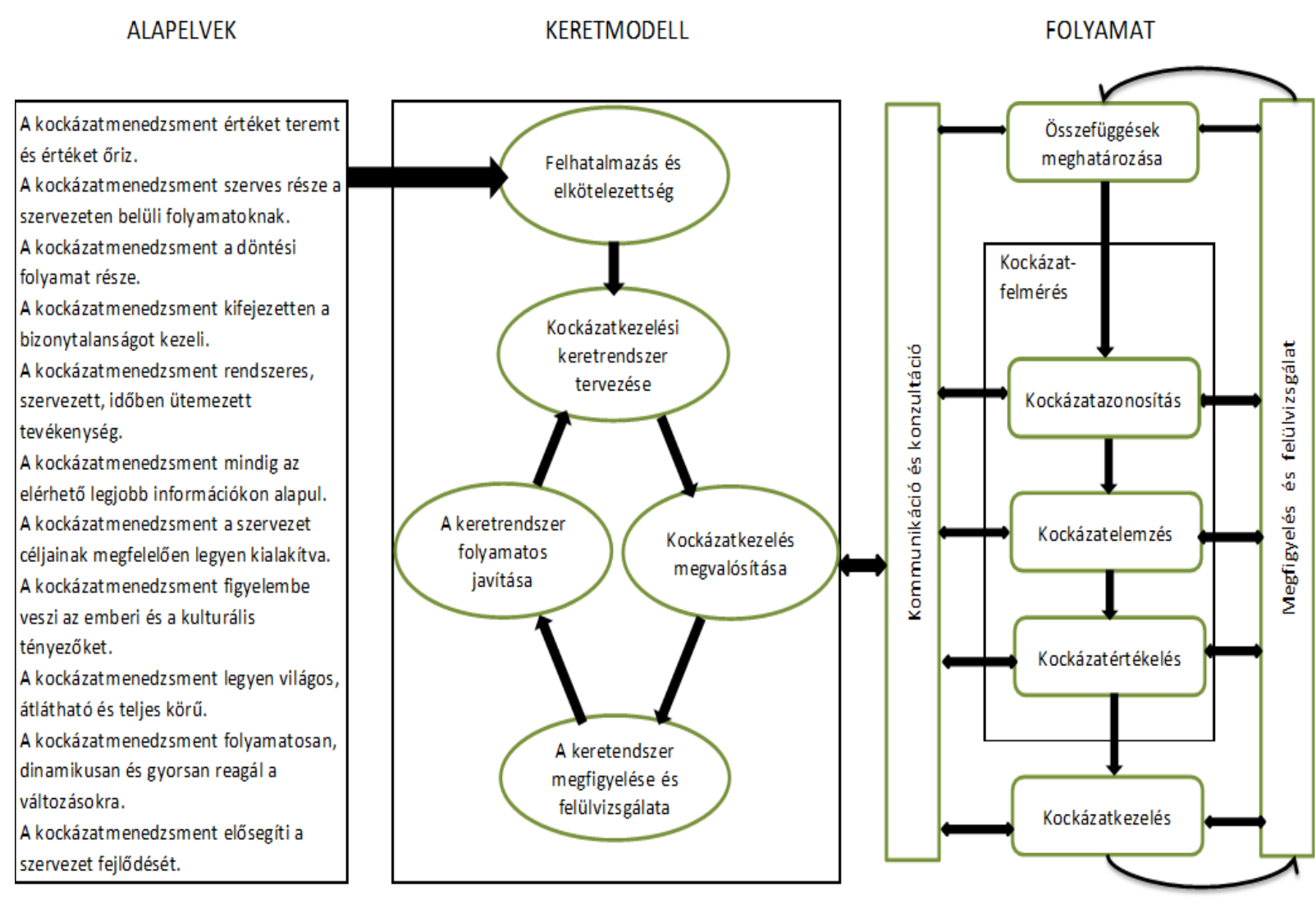

1. ábra: Kapcsolat a kockázatmenedzsment elvei, keretmodellje és folyamata között

(Forrás:ISO 31010:2009)

Az ISO 31010:2009 szabvány által leírt kockázatkezelési folyamat elemei a vállalati célok által vezérelt kockázatkezelési ciklusok lépéseit határozzák meg. A kockázatfelmérés alapján megvalósított kockázatkezelési intézkedések után fennmaradó maradványkockázatok a következő kockázatkezelési ciklus tervezésének kiindulópontját képezik.

Az ISO 31000 szabvány szerinti kockázatkezelés megvalósítása jelentős szemléletváltást jelent a hagyományos kontroll- vagy megfelelés központú kockázatkezeléshez képest, amelyeknél a különböző hatósági elő́rásoknak, szabványoknak, illetve ajánlott keretrendszereknek való megfelelés „kényszere" determinálja a kockázatkezelés súlyponti területeit. A vállalati kockázatkezelés folyamatait gyakorlatilag alárendeli a külső felülvizsgálatokat, auditokat és tanúsítási eljárásokat lefolytató szervezetek, könyvvizsgálók, tanúsítók[12]. A szabvány a vállalatirányítási rendszer hatékonyabbá tételéhez kíván hozzájárulni. Ehhez pedig nem a hagyományos auditálásokra és tanúsítási eljárásokra való felkészüléseken, hanem az üzleti környezet elvárásait és a sajátos üzleti célokat figyelembe vevő kockázatkezelési folyamatok alkalmazása a cél.

A kockázatkezelés szabvány szerinti folyamatai lényegében a múködési és szervezeti szintek irányítási feladatainak, vagyis az üzleti működési és szervezetirányítási folyamatoknak vezetői ellenőrzés alatt tartását valósítják meg. A kockázatkezelési folyamat csak az érintett működési terület külső és belső összefüggéseinek vonatkozásában értelmezhető. 


\subsection{M_o_R modell}

A M_o_R egy mozaik szó: Management of Risk rövidítése. Ez egy kockázatkezelési keretrendszer elnevezése, melyet 2002-ben tettek közzé azzal a céllal, hogy segítséget nyújtson a szervezetek számára egy hatékonyan múködő belső rendszer kialakítására, hogy a szervezetben felmerülő kockázatokat megalapozott döntések alapján lehessen kezelni [13]. A modell összeköti az irányelveket, a megközelítést és egy sor egymással összefüggő folyamatot, és részletes segítséget ad a kockázatkezelési technikák és módszerek alkalmazásához [11].

A M_o_R modell egyesíti a kockázatkezelés egy általános megközelítését a konkrét folyamatokkal és irányelvekkel. Megmutatja a szervezeteknek, hogy hogyan lehet a kockázatkezelési tevékenységet beépíteni a szervezet múködésébe, és ezt hogyan lehet felülvizsgálni, és ahol szükséges, a folyamatot a változó körülményekhez igazítani. A keretrendszer az alábbi részekre tagozódik [11]

M_o_R alapelvek: A kockázatkezelés ebben a modellben, a belső ellenőrzés részének tekinthető, amit az alapelvek is alátámasztanak. Tizenkét elv, melyeket a „legjobb gyakorlat” és a vállalatirányítási elvekből alakítottak ki.

- A szervezeti háttér biztosítása

- Érdekelt felek bevonása a kockázatkezelési folyamatba

- Szervezeti célok, célkitűzések meghatározása

- M_o_R megközelítés alkalmazása

- Jelentések készítése

- Teendők és a felelősök kijelölése

- Támogató vállalati szerkezet meghatározása

- Korai „figyelmeztető mutatószámok” megadása

- Felülvizsgálati körfolyamat alkalmazása

- M_o_R bevezetés miatti akadályok megszűntetése

- Támogató vállalati kultúra kialakítása

- A keretrendszer folyamatos fejlesztése

M_o_R megközelítés: Az elveket a szervezetre kell igazítani és alkalmazni, majd ezeket az alapelveket az egyes szervezeti egységekre lebontva kell meghatározni és elfogadtatni. Az így meghatározott és elfogadott elveket a kockázatkezelési politikában, a folyamat-leírásokban és a különböző szintű tervekben érvényesíteni kell.

M_o_R folyamat: A kockázatkezelés folyamata ebben a modellben az alábbi tevékenységekre tagolódik. Ezek a lépések biztosítják azt, hogy a szervezetben felmerülő kockázatokat szisztematikusan azonosítják, értékelik és ellenőrzik.

- Kockázat azonosítás

- Kockázat értékelés 
- Kockázatkezelési válaszok meghatározása

- Kockázatkezelési válaszok végrehajtása, a végrehajtás ellenőrzése

M_o_R beágyazása és felülvizsgálata: A keretrendszer előbbi három részét be kell építeni a szervezet ellenőrzési folyamataiba.

A M_o_R ajánlásokat tesz a szervezetek számára, hogy hogyan lehet az irányelveket, a megközelítést és a kockázatkezelési folyamatokat beépíteni, felülvizsgálni, majd differenciáltan alkalmazni ezeket attól függően, hogy éppen milyen eredetű kockázatok kezeléséről van szó.

\subsection{GCR modell}

GRC (Governance, Risk Management, and Compliance) képességi modell: Az Irányítási Kockázatkezelési és Megfelelőségi modell, amely három elemből áll, ezek együttes hatásukkal biztosítják, hogy a szervezet a kitűzött céljait elérje [10]. Az elnevezésből is látható, hogy ez nem „csak” egy kockázatkezeléssel foglalkozó rendszer. GRC modell elemei a következők:

- Irányítás (Governance) - a szervezet vezetése által megalapozott és végrehajtott folyamatok kombinációja, amelyek visszatükröződnek a szervezeti felépítésben és abban, ahogyan sikerül a kitűzött célokat elérni.

- Kockázatkezelés (Risk Management) -azoknak a kockázatoknak előrejelzését és kezelését jelenti,amely kockázatok hátráltatják a szervezetet abban, hogy a kitűzött célokat elérje.

- Megfelelés (Compliance) - a vállalat belső szabályozásának és folyamatainak megfelelése a jogszabványoknak, előírásoknak. Ennek teljesüléséhez határozott és hatékony vállalatirányítás szükséges.

A GRC egy ismeretanyag, az alkalmazásnak célja, hogy összehangolja az információkat és a szervezet tevékenységeit az irányítással, a kockázatkezeléssel és a megfeleléssel, annak érdekében, hogy

- a szervezet múködése eredményesebb legyen,

- hatékonyabb legyen az információ megosztása az egyes szervezeti egységek között,

- a jelentési kötelezettség hatékonysága növekedjen, úgy hogy,

- elkerüljék a pazarló átfedéseket a szervezet tevékenységeiben [10].

Habár a különböző szervezetekben más-más módon alkalmazzák a GRC képességi modellt, mégis bizonyos tevékenységek minden szervezetben jelen vannak, mint például, a vállalatirányítás rendszere, a vállalati kockázatkezelés, vagy a megfelelés.

A GCR modellnek nyolc integrált összetevője van, melyek együttesen vannak hatással a vállalkozás üzleti eredményeire. Ezek az összetevők a következők [10]:

- Az üzleti célkitűzések elérése.

- Szervezeti kultúra erősítése.

- Az érdekeltek bizalmának növelése.

- A szervezet felkészítése és védelme. 
- A kellemetlen események észlelése, bekövetkezésük megelőzése, csökkentése.

- A vállalat dolgozóinak motiválása - a kívánt hozzáállás elérése az kitűzött célok megvalósítása érdekében.

- Hatékonyság javítása.

- Optimalizálja a gazdasági, társadalmi értékeket.

Amikor egy szervezet/vállalkozás elér egy bizonyos méretnagyságot, ahol már elvárás az eredményes működés, ott szükség van a tevékenységek összehangolt ellenőrzésére a GRC modell segítségével. Abban az esetben, ha a szervezeten belül a vállalatirányítási rendszer, a kockázatkezelés és a vállalati megfelelés egymástól függetlenül működik, akkor jelentősen megnő a vállalaton belüli párhuzamos munkavégzés.

\section{4. Összefoglalás}

A felelős vállalatirányításban és vállalati kultúrában ma már nélkülözhetetlen a kockázati események tudatosítása, felismerése. A vállalati kockázatkezelésnek be kell ágyazódnia a vállalatirányítás rendszerébe. A kockázatkezelési folyamatnak a tervezési folyamat részfolyamataként kell beépülnie a vállalat rendszerébe. A vállaltirányítás legfontosabb feladata a jövőre vonatkozó elképzelések felvázolása, és az azok megvalósításával kapcsolatos döntések meghozatala. A tervezés olyan irányítási folyamat, amely felvázolja a vállalat jövőbeni működésének pályáját, az azt jellemző állapotokat, pozíciókat [6].

A kockázati kitettségnek a mérséklése és az egyes kockázatokkal arányos mértékű védelem kidolgozása, azaz a kockázatok elemzése, tervezése lehetőséget ad

- a megfelelő stratégiák, tervek kidolgozására, melyek hatékony és időben történő beavatkozásra adnak módot,

- a kockázatosnak minősített folyamatok átalakításához szükséges intézkedések időbeni végrehajtásához,

- a rosszul működő szervezeti egységek, szerkezeti elemeket kijavítására, módosítására.

Ezeknek a tevékenységeknek az eredményeképpen a vállalkozás növelheti a jövedelemtermelő képességének a hatékonyságát és növelheti az egyes megtérülési mutatók értékét.

Mind a négy modellben a kockázatkezelés két főbb komponense ismerhető fel. Az egyik egy „keretmodell” alkalmazása, a másik a kockázatkezelés szúkebb értelemben vett „folyamata”. A keretmodell egy speciális nyelvezetként fogható fel. Az ERM a kockázatokkal kapcsolatban teendők meghatározását a kockázatviselési szint és kockázatviselési hajlandóság fogalmak köré építi. Az ISO konkrétan megad egy keretmodellt (így is nevezi), a MoR tizenkét alapelvet fogalmaz meg, a GCR pedig nyolc lépést határoz meg. A kockázat kezelés „folyamata” alapvetően azonos: a kockázatok azonosításával, értékelésével és/vagy elemezésével és kezelésével. Az EMR objektív mutatószámokat állít fel, és azok alapján végzi a folyamatot. Az ISO egy algoritmust ad meg (hat elemből). A MoR a folyamatot négy lépésben írja le. A GCR a nyolc lépés között az ötödikben három teendôvel határozza meg a kockázatkezelés folyamatát. 
Az ismertetett kockázatkezelési modellek tehát egymástól eltérő eljárásokat használva, de minden esetben bizonyos nem kívánt események káros hatásait és azok egymáshoz viszonyított kockázati rangsorát határozzák meg. Mindegyik modell esetében felismerhető a kockázatkezelés általános folyamata, amelynek a lépései az alábbiak, és bármilyen kockázat esetén hasonló lépések alapján zajlik. Azonos lépésekként az alábbiak jelölhetők meg.

- Kockázat azonosítás

- Kockázat értékelés és elemzés

- Kockázatok kezelése

- Kockázatok felülvizsgálata, megfigyelése

Ugyanakkor vannak eltérések az egyes keretrendszerek között. Ezekre a következő példák adhatók.

- Különböző módszerekkel azonosítják a kockázatokat a kockázatkezelés folyamatában

- Különbözőképpen becsülik a kockázatok bekövetkezési valószínúségét, valamint a várható kár mértékét

- Különböző módszerekkel értékelik ki a kockázatokat

- Eltérő módszereket alkalmaznak a kockázati érték meghatározásában

- Eltérő módon reagálnak a kockázatokra

\section{Hivatkozások}

[1] R. Banham (2004), Enterprising Views of Risk Management, Journal of Accountancy, 197(6) pp: 65-71

[2] Casualty Actuarial Society (CAS) Enterprise Risk Management Committee (2003), Overview of Enterprise Risk Management, from www.casact.org

[3] COSO (2004), Enterprise Risk Management - Integrated Framework: Executive Summary, from www.coso.org

[4] International Organization for Standardization (2009), ISO 31000:2009 Risk managementPrinciples and Guidelines

[5] International Organization for Standardization (2009), ISO 31010:2009 Risk managementRisk Assessment Techniques

[6] T. Jelen, T. Mészáros (2008), Tervezés, Aula Kiadó, Budapest

[7] T. Jenei (2012), Kockázatelemzés, kockázatkezelés, kockázatkezelési stratégiák, különös tekintettel a geotermikus beruházásokra, XVIII. Épületgépészeti, Gépészeti és Építőipari Szakkiállítás és Nemzetközi Tudományos Konferencia, Debreceni Egyetem Műszaki Kar, Konferencia kiadvány, Debrecen, 2012. október 11-12. ISBN: 978-963-473-591-5, papercode: MAN 12-01. 
[8] T. Jenei (2014), A vállalati gazdasági folyamatok kockázatkezelésének elemzése az ISO 31000 és az ISO 31010 szabványok követelményeinek alkalmazása esetén, In Edit Szűcs, Mariann Veresné Somosi, Andrea Matkó, Judit T. Kiss, Tibor Balla (szerk.) „Proceedings of Challenges and Lessonsin Management" International Conference, Volume: 2. Konferencia helye ideje: Debreceni Egyetem Debrecen, 2014. október 09. (ISBN: 978-963-473-747-6)

[9] T. Jenei (2014), Geotermikus beruházások kockázatainak elemzése, Debrecen, Debreceni Egyetem 2014 ISBN: 978-963-473-780-3 pp: 120.

[10] OCEG, GRC Capabilitiy Model Red Book 2.0, download after registration from www.oceg.org

[11] Office of Government Commerce (2007), Management of Risk 2007 edition: Guiadance for Practitioners, The Stationery Office

[12] Trusted Business Partners Kft (2014), Kockázatkezelési kézikönyv - Irányítási forgatókönyvek alkalmazása az integrált vállalati kockázatkezelés megvalósítására 2014, (szerk: Iványosi János) www.trusted.hu

[13] Williams Graham, Management of Risk $\left(M_{-} o_{-} R\right)$ - The facts a good, simple explanation, download from www.mor-officialsite.com 